Rev. Int. Contam. Ambie. 35 (3) 553-563, 2019

DOI: 10.20937/RICA.2019.35.03.03

\title{
AZOXYSTROBIN INDUCES CHROMOSOMAL ABERRATIONS IN ROOTS OF THE HYDROPHYTE Bidens laevis L.
}

La azoxistrobina induce aberraciones cromosómicas en raíces de la hidrófita Bidens laevis L.

\author{
Débora Jesabel PÉREZ ${ }^{1,2 *}$, Mirta Luján MENONE ${ }^{1,3}$, \\ Jorge Alberto TOGNETTI ${ }^{4,5}$ and Germán LUKASZEWICZ ${ }^{1,3}$
}

${ }^{1}$ Laboratorio de Ecotoxicología, Facultad de Ciencias Exactas y Naturales, Universidad Nacional de Mar del Plata, Dean Funes 3350, Código Postal 7600, Mar del Plata, Argentina

${ }^{2}$ Consejo Nacional de Investigaciones Científicas y Técnicas, Godoy Cruz 2290, Código Postal C1425FQB, Ciudad Autónoma de Buenos Aires, Argentina

${ }^{3}$ Instituto de Investigaciones Marinas y Costeras, Consejo Nacional de Investigaciones Científicas y TécnicasUniversidad Nacional de Mar del Plata, Dean Funes 3350, Código Postal 7600, Mar del Plata, Argentina

${ }^{4}$ Laboratorio de Fisiología Vegetal, Facultad de Ciencias Agrarias, Universidad Nacional de Mar del Plata, Ruta Nacional 226, km 73.5, Código Postal 7620, Balcarce, Buenos Aires, Argentina

${ }^{5}$ Comisión de Investigaciones Científicas, Calle 526 entre 10 y 11, Código Postal 1900, La Plata, Buenos Aires, Argentina

*Corresponding author: perez.debora@inta.gob.ar

(Received October 2017; accepted September 2018)

Key words: wetland plant, strobilurin fungicide, cytogenetic biomarkers, chlorophylls, chlorophyll fluorescence

\begin{abstract}
Aquatic plants can be used as in situ bioindicators of water quality due to their ability to accumulate agrochemicals. However, these plants may be at significant ecotoxicological risk from pesticides applied in crop fields. The fungicide azoxystrobin (AZX) induces DNA damage and changes in the antioxidant enzymatic system in leaves of the submerged hydrophyte Myriophyllum quitense. In the present study, the objectives were to determine whether AZX induces chromosomal damage in roots of the wetland plant Bidens laevis and to evaluate whether the damage in the antioxidant system was associated with damage in the photosynthetic system. Two experiments were carried out to evaluate the short-term effects ( 1 or 2 days) of the exposure to different concentrations of the active ingredient of AZX $(0,0.1,1,10,50,100 \mu \mathrm{g} / \mathrm{L})$ on intact $B$. laevis plants. In the first experiment, photosynthetic biomarkers, including chlorophyll a fluorescence, SPAD units, and chlorophyll a and $\mathrm{b}$ content, were measured. In the second experiment, the frequency of chromosome aberrations (CA) was evaluated in root tips. In general, the photosynthetic biomarkers evaluated were not affected by AZX, except for a decrease in chlorophyll b content at $100 \mu \mathrm{g} / \mathrm{L}$. Total CA increased at all AZX concentrations and the most frequent abnormalities were laggards and chromosomes not congregated at the metaphase equator, both indicators of spindle disturbance. This is the first report of AZX-induced chromosomal aberrations in a wetland plant exposed to environmentally relevant concentrations of the fungicide. The reason why AZX exposure had only a limited impact on biomarkers of the photosynthetic apparatus is discussed.
\end{abstract}


Palabras clave: planta de humedal, fungicida estrobilurínico, biomarcadores citogenéticos, clorofilas, fluorescencia de clorofila

\section{RESUMEN}

Las plantas acuáticas pueden usarse como bioindicadores in situ de la calidad del agua debido a su capacidad de acumular agroquímicos. Sin embargo, estas plantas pueden estar en riesgo ecotoxicológico significativo debido a los plaguicidas aplicados en los campos de cultivo. El fungicida azoxistrobina (AZX) induce daño al ADN y provoca cambios en el sistema enzimático antioxidante en hojas de la hidrófita sumergida Myriophyllum quitense. En este trabajo, nuestros objetivos fueron determinar si la AZX induce daño cromosómico en raíces y evaluar si el daño en el sistema antioxidante se asociaría con daños en el sistema fotosintético en la planta de humedal Bidens laevis. Se llevaron a cabo dos experimentos para evaluar los efectos a corto plazo (1 o 2 días) en plantas intactas de $B$. laevis expuestas desde la raíz a diferentes concentraciones del ingrediente activo $(0,0.1,1,10,50,100 \mu \mathrm{g} / \mathrm{L})$ de AZX. En el primer experimento, se midieron biomarcadores fotosintéticos, que incluyeron fluorescencia de clorofila a, unidades SPAD y contenido de clorofila a y b. En el segundo experimento, se determinó la frecuencia de aberraciones cromosómicas (CA) en ápices de raíz. En general, los biomarcadores fotosintéticos no se vieron afectados por AZX, excepto por una disminución del contenido de clorofila b a $100 \mu \mathrm{g} / \mathrm{L}$. La frecuencia de CA aumentó en todos los tratamientos con AZX y las anormalidades más frecuentes fueron cromosomas rezagados y cromosomas no congregados, ambos indicadores de alteración del huso mitótico. Éste es el primer informe en el cual AZX induce aberraciones cromosómicas en una planta de humedal expuesta a concentraciones ambientalmente relevantes del fungicida. Se discute la razón por la cual la exposición a AZX tuvo un impacto limitado en los biomarcadores fotosintéticos.

\section{INTRODUCTION}

Macrophytes have a variety of roles in maintaining the physical and chemical functioning of freshwater ecosystems. They also provide habitats for other plants (particularly epiphytic algae) and animals, food for invertebrates and vertebrates (birds and fishes), and oviposition sites for invertebrates and fishes (Malby et al. 2010).

Therefore, the macrophytes are important in the agricultural landscape because they carry out a range of ecosystem functions that help to maintain the integrity of freshwater systems (Maltby et al. 2010).

In aquatic environments, pesticides might freely dissolve in the water or bind to suspended matter and sediments, and might be transferred to the organism's tissues during bioaccumulation processes, resulting in adverse consequences to non-target species (Rodrigues et al. 2013), which can be observed and measured throughout biomarkers.

Biomarkers can be defined as measurable changes at the molecular, biochemical, cellular, physiological or behavioral levels in response to exposure to chemical contaminants and/or their effects (Gupta 2014). In this sense, the biomarkers can be used to understand the exposure of organisms to biologically available environmental pollutants (biomarker of exposure) and to quantify their effects (biomarker of effects) (Hugget et al. 1992).

These responses represent early warning systems of sublethal stress, which help to predict environmental risks and to define an efficient biological alert system (Hugget et al. 1992). In plants, several biomarkers, such as antioxidant enzymes (e.g. catalase and peroxidase activities), chlorophyll content, photosynthetic oxygen production, and chromosomal aberrations, are commonly used.

Among genetic biomarkers, cytogenetic biomarkers such as chromosomal aberrations in mitotic and meiotic cells and micronuclei are widely used and may be considered as highly sensitive biomarkers of early effects.

There are two types of possible mechanisms of the formation of chromosome aberrations in plant mitotic cells, which depend on the mode of action of the genotoxic agent. Aneugenic agents interfere with the normal formation of the mitotic spindle or interrupt the binding of the kinetochore to the tubulin 
fibers, while clastogenic agents induce breaks in DNA chains (Rank 2003).

Regarding physiological biomarkers, it has been shown that chlorophyll and carotenoid contents, both considered as biomarkers of early effects, are either equally or more sensitive stress indicators than biomass or relative growth rate (Brain and Cedergreen 2008).

In fact, if the contaminant disrupts photosynthesis or pigment biosynthesis, chlorophyll and carotenoid contents can be easy-to-measure and robust biomarkers, amenable to both laboratory- and field-based investigations (Brain and Cedergreen 2008).

In addition, chlorophyll a fluorescence (ChlaF) can be used to study the photosynthetic electron transport capacity of any plant. In fact, measurements of ChlaF have been widely used to study plant photosynthesis and stress response to "non-herbicidal" pesticides (Krugh and Miles 1996) and chromium (Nichols et al. 2000), among other pollutants. Indeed, both hydrophilic and lipophilic compounds have been shown to affect fluorescence parameters in aquatic plants and algae at earlier times (Brain and Cedergreen 2008).

The chemical destructive methods traditionally used for chlorophyll quantification required pigment extraction in a solvent and spectrophotometric determination of absorbance, which are relatively timeconsuming. Thus, non-destructive optical methods based on the absorbance and fluorescence emission of light by the intact leaf were developed. Among them, Soil Plant Analysis Development (SPAD) is used to measure chlorophyll content, while ChlaF measures the potential yield of the photochemical reaction of photosystem II (PS II) (Krugh and Miles 1996, Richardson et al. 2001).

Bidens laevis L. (smooth beggartick) is a wetland perennial herbaceous plant widespread in North, Central and South America (Lahitte and Hurrell 1997). This species possesses particularly suitable cytological characteristics to perform genotoxicity tests, such as a high percentage of seed germination $(>70 \%)$, almost null mortality of seedlings and young plants, large and clearly visible chromosomes, and a relatively low somatic chromosome number of $2 \mathrm{n}=24$ (Menone et al. 2015).

Previous works have shown that $B$. laevis shows high sensitivity to different toxicants (including pesticides and recognized mutagens), evaluated through chromosomal aberrations and enzymatic and molecular biomarkers (Pérez et al. 2008, 2011, 2014).

Strobilurin fungicides are considered a very valuable tool in agriculture, because of their apparent dual role in crop production: they provide plant protection from pathogenic fungi, and allegedly induce physiological and hormonal changes in plants, which may lead, in the long-run, to enhanced plant growth (Grossman and Retzlaff 1997, Balba 2007).

The mode of action of strobilurin fungicides involves the inhibition of mitochondrial respiration in pathogenic fungi by their binding to the $\mathrm{Q}_{0}$ site of the cytochrome-bc1 complex located in the inner mitochondrial membrane (Bartlett et al. 2002), which then leads to a decrease in ATP synthesis.

Although these fungicides were originally designed to control fungal pathogens, their mode of action is not specific to fungi, so they can be potentially toxic to a wide range of non-target organisms (Rodrigues et al. 2013).

Garanzini and Menone (2015) have recently reported that the fungicide azoxystrobin (AZX) causes phytotoxic and genotoxic effects in the aquatic submerged macrophyte Myriophyllum quitense, by inducing changes in the antioxidant system and DNA fragmentation. In that study, the active ingredient of AZX was in contact with the whole body plant, being able to be uptaken by the roots, stem and leaves. However, information concerning other potential effects on plants is scarce.

Particularly in wetland plants, whether AZX can be uptaken from roots and translocated to aboveground tissues is not known. If AZX translocates to leaves, possible negative effects on the chloroplast electron transport chain could be expected, and this potential effect could be evidenced as damage in the photosynthetic apparatus.

In a study performed by Battaglin et al. (2011) in the USA, AZX was the fungicide most frequently detected (45\% of 103 samples) in 17 sites of 11 states, reaching maximum concentrations of 1.13 $\mu \mathrm{g} / \mathrm{L}$, whereas in a study by Berenzen et al. (2008) in streams in Braunschweig (northern Germany), AZX levels were as high as $29.7 \mu \mathrm{g} / \mathrm{L}$.

In Argentina, although AZX is extensively applied in several crops, as wheat, corn, barley, potato and rape (Pérez et al. 2017), little is known about AZX levels in aquatic ecosystems. In this sense, the risk of AZX to reach aquatic ecosystems and to induce adverse effects on wetland organisms creates a high concern.

For this reason, the objectives of the present work were to assess whether the fungicide AZX induces chromosomal damage in roots of the wetland macrophyte $B$. laevis and/or photosynthetic system damage in leaves, shortly after a brief ( 1 or 2 days) exposure. 


\section{MATERIALS AND METHODS}

\section{Chemicals}

Azoxystrobin [(methyl (E)-2-2-(6-(2-cyanophenoxy) pyrimidine-4-yloxy) phenyl-3-methoxyacrylate)] (CAS: 131860-33-8) and methyl methanesulfonate (MMS) (CAS: 66-27-3) reference standard (purity $>95 \%$ ) were purchased from Sigma-Aldrich. These compounds were used as received from the company without any additional purification. Dimethyl sulfoxide (DMSO, Mallinckrodt) and N,Ndimethylformamide (N,N-DMFA, ACS Reagents), which were used as solvents, were purchased from a local seller.

\section{Plant material}

Seeds of B. laevis were collected from La Brava Lake ( $\left.37^{\circ} 53^{\prime} \mathrm{S}, 57^{\circ} 59^{\prime} \mathrm{W}\right)$, Argentina, in May 2013, and then stored in paper bags in darkness and without humidity until use. Seeds were sterilized in a $30 \%$ solution of commercial bleach (DEM Argentina, $5.5 \mathrm{~g} / \mathrm{L}$ ) for $5 \mathrm{~min}$, rinsed several times in distilled water, and placed in Petri dishes with damp filter paper for germination at $20^{\circ} \mathrm{C}$.

Rooted seedlings were transferred to soil-containing pots and maintained for two months until full expansion of the first emergent leaf and appearance of the third pair of leaves. Prior to the start of the exposure, two-month-old plants were removed from the pots, and carefully rinsed in tap water to remove the soil.

\section{Experimental solutions and design}

Stock solutions of pure AZX were prepared in DMSO in a concentration of $2000 \mathrm{mg} / \mathrm{L}$. AZX treatments were prepared by diluting the corresponding volume of stock solution in Hoagland medium to a final volume of $350 \mathrm{~mL}$. Thereby, the five final exposure solutions of AZX contained 0.1, 1, 10, 50 and $100 \mu \mathrm{g} / \mathrm{L}$ of active ingredient and $0.004 \%$ of DMSO.

In addition, the following control exposure solutions were used: one negative control (Co-1), with Hoagland Solution; another negative control (Co-2) in which DMSO was added to the Hoagland solution at $0.004 \%$ (similar to the concentration of DMSO used for the AZX exposures); and one positive mutagenic control $(\mathrm{Co}+)$ consisting of $10 \mathrm{mg} / \mathrm{L}$ of MMS in Hoagland solution, used only in the cytogenetic analysis.

A total of 90 plants in the same physiological stage were selected to perform the experiments. One set of 42 plants $(n=6$ per each treatment) for experiment 1 (photosynthetic biomarkers) and one set of
48 plants for experiment 2 (cytogenetic biomarkers) were randomly placed into individual $350-\mathrm{mL}$ glass flasks containing a known exposure solution.

A piece of aluminum foil was used to cover the flasks to provide support to the stems and darkness to the roots. In this sense, the flasks only served as the container for root exposure.

For photosynthetic biomarkers, a 24-h exposure was performed, whereas for cytogenetic biomarkers, a 48-h exposure followed by a recovery period of 24 $\mathrm{h}$ in Hoagland solution was used to allow the completion of the cell cycle of the exposed cells (Grant and Owens 2002).

Both experiments were carried out in a controlledenvironment chamber $(12 \mathrm{~h}$ light $/ 12 \mathrm{~h}$ darkness at $22^{\circ} \mathrm{C}$ ). The photosynthetic and cytogenetic biomarkers were measured at the end of the exposures.

\section{Experiment 1: Photosynthetic biomarkers Non-destructive methods Chlorophyll a fluorescence}

A portable chlorophyll fluorescence meter (Z990 Fluorpen Handheld Chlorophyll Fluorometer, System Inc., Canada) was used to measure ChlaF through the $\mathrm{Fv} / \mathrm{Fm}$ ratio (where $\mathrm{Fv}$ is the maximum variable fluorescence emission and Fm is the maximum total fluorescence).

Each measurement was done in triplicate on the youngest fully expanded leaf. Data were expressed as the average value of the $\mathrm{Fv} / \mathrm{Fm}$ ratio per plant and in terms of the average \pm standard error (SE) for each treatment.

\section{Chlorophyll content (SPAD measurement)}

The total chlorophyll content was measured as SPAD values (Minolta SPAD-502 chlorophyll meter) in triplicate on the youngest fully expanded leaf. Data were expressed as the average of SPAD values per plant and in terms of the average \pm SE for each treatment.

\section{Destructive methods}

\section{Chlorophyll content (chemical extraction)}

Sample preparation and spectrophotometric measurement: Immediately after fluorescence and SPAD determination, leaf discs $(0.2 \mathrm{~g})$ of the youngest fully expanded leaf were placed into 10 - $\mathrm{mL}$ vials with 2 $\mathrm{mL}$ of N,N-DMFA for $72 \mathrm{~h}$ at $4{ }^{\circ} \mathrm{C}$ in darkness. An aliquot of $1 \mathrm{~mL}$ was placed into the spectrophotometric vial to assess chlorophyll a (Chla) at 664.5 $\mathrm{nm}$ and chlorophyll b (Chlb) at $647 \mathrm{~nm}$.

A spectrophotometer Bausch \& Lomb model Spectronic 20 was used to measure the chlorophyll 
pigments. The formulas used to calculate the concentrations of Chla, Chlb and total chlorophyll (TCh) were the following:

Chla $=[12.7 \times$ OD $664.5 \mathrm{~nm}]-[2.79 \times$ OD $647 \mathrm{~nm}]$ $\mathrm{Chlb}=[20.7 \times$ OD $647 \mathrm{~nm}]-[4.62 \times$ OD $664.5 \mathrm{~nm}]$ $\mathrm{TCh}=[17.9 \times \mathrm{OD} 664.5 \mathrm{~nm}]+[8.08 \times \mathrm{OD} 647 \mathrm{~nm}]$

where the coefficients represent the molar extinction coefficients of Chla and Chlb in N,N-DMFA(Inskeep and Bloom 1985).

In addition, the ratio between Chla and Chlb (Chla/b) was calculated. Data were expressed as mg of Chla, Chlb and TCh per $\mathrm{g}$ of fresh tissue in each plant, and in terms of the average \pm SE for each treatment.

\section{Experiment 2: Cytogenetic biomarkers}

Root tips ( $1 \mathrm{~cm}$ long) were fixed in ethanol:glacial acetic acid $(3: 1, \mathrm{v} / \mathrm{v})$ for $24 \mathrm{~h}$ and maintained in $70 \%$ ethanol in a refrigerator until analysis. Then, they were macerated in $1 \mathrm{M} \mathrm{HCl}$ at $60{ }^{\circ} \mathrm{C}$ for $10 \mathrm{~min}$, stained with Feulgen reagent for $2 \mathrm{~h}$ in darkness, squashed in a solution of $1-2 \%$ carmine in $45 \%$ acetic acid, and observed in an optical microscope Olympus CX31.

For all cytogenetic biomarkers, one or more slides per plant were prepared to observe the number of cells required at each stage of mitosis. In this sense, the mitotic index (MI) was calculated as the number of cells at any stage of mitosis per 1000 observed cells per plant. This parameter was measured to confirm that the number of mitotic cells was high enough to carry out the analysis of chromosome aberrations (Pérez et al. 2014).

The MI was expressed as a percentage of cells in mitosis for each plant and in terms of the average \pm SE for each treatment.

\section{Chromosomal aberrations in metaphase}

One hundred cells in metaphase per plant were observed to score chromosomal aberrations in metaphase (CAM), which included chromosomes not congregated at the metaphase equator. Data were expressed as a percentage of CAM/100 metaphases for each plant and in terms of the average $\pm \mathrm{SE}$ for each treatment.

\section{Chromosomal aberrations in anaphase-telophase}

Two hundred cells in anaphase-telophase per plant were observed, and the different chromosomal aberrations in anaphase-telophase (CAAT), including bridges, fragments, vagrants and laggards, were scored. Data were expressed as a percentage of each type of CAAT/200 anaphase-telophases per plant and in terms of the average \pm SE for each treatment.

\section{Other chromosomal aberrations}

Other chromosomal aberrations (OCA) such as colchicine mitosis (c-mitosis) and chromosome clumping were also observed and scored. Data were expressed as a percentage of OCA/200 anaphasestelophases for each plant and in terms of the average \pm SE for each treatment.

\section{Total chromosomal aberrations}

Total chromosomal aberrations (CA) were calculated as the percentage of chromosomal aberrations in 300 mitotic cells scored (100 cells in metaphase plus 200 cells in anaphase-telophase).

\section{Statistical analyses \\ Photosynthetic biomarkers}

As the values of all variables were continuous, normality and homogeneity of residuals were first verified by Shapiro-Wilk and Levene tests, respectively, and then, parametric tests were applied to analyze differences in these biomarkers. In this regard, ANOVA was applied and, a posteriori, differences between treatments were tested by Tukey's test.

\section{Cytogenetic biomarkers}

As the values of all variables were discrete, data were first analyzed as a percentage and later transformed using the arcsine function to apply a parametric statistical test. In this regard, ANOVA was applied and, a posteriori, differences between treatments were tested by Tukey's test.

Statistical analyses were carried out using the $\mathrm{R}$ software package (v. 3.2.2.), with 0.05 and $0.01 \%$ significance levels.

\section{RESULTS}

\section{Experiment 1: Photosynthetic biomarkers Non-destructive methods}

The ChlaF and chlorophyll content measured with SPAD showed no statistically significant changes at any of the AZX concentrations tested with respect to the negative controls $(\mathrm{p}>0.05)$ (Table I).

\section{Destructive methods}

The TCh and Chla showed no statistically significant changes at any of the AZX concentrations tested with respect to the negative controls $(\mathrm{p}>0.05)$ (Table I). However, Chlb showed a statistically significant 
TABLE I. PHOTOSYNTHETIC BIOMARKERS IN LEAVES OF Bidens laevis EXPOSED TO DIFFERENT AZOXYSTROBIN TREATMENTS. AVERAGE OF SIX REPLICATES \pm STANDARD ERROR

\begin{tabular}{|c|c|c|c|c|c|c|}
\hline \multirow{2}{*}{ Treatment } & \multicolumn{2}{|c|}{ Non-destructive methods } & \multicolumn{4}{|c|}{ Destructive methods } \\
\hline & ChlaF & SPAD & TChl & Chla & Chlb & Chla/b Ratio \\
\hline Co-1 & $0.66 \pm 0.01$ & $29.64 \pm 0.93$ & $567.73 \pm 43.80$ & $416.10 \pm 37.39$ & $151.77 \pm 9.92$ & $2.75 \pm 0.23$ \\
\hline $\mathrm{Co}-2$ & $0.67 \pm 0.01$ & $33.56 \pm 1.22$ & $608.43 \pm 20.28$ & $446.53 \pm 10.74$ & $162.06 \pm 7.92$ & $2.79 \pm 0.21$ \\
\hline $0.1 \mu \mathrm{g} / \mathrm{L}$ & $0.68 \pm 0.01$ & $33.28 \pm 1.21$ & $614.66 \pm 29.36$ & $435.95 \pm 22.81$ & $178.88 \pm 6.74$ & $2.43 \pm 0.04$ \\
\hline $1 \mu \mathrm{g} / \mathrm{L}$ & $0.69 \pm 0.00$ & $30.72 \pm 0.64$ & $575.21 \pm 28.82$ & $430.50 \pm 17.86$ & $144.86 \pm 11.56$ & $3.02 \pm 0.17$ \\
\hline $10 \mu \mathrm{g} / \mathrm{L}$ & $0.68 \pm 0.01$ & $32.03 \pm 1.18$ & $596.71 \pm 21.49$ & $444.00 \pm 17.41$ & $152.87 \pm 9.32$ & $2.90 \pm 0.04$ \\
\hline $50 \mu \mathrm{g} / \mathrm{L}$ & $0.63 \pm 0.02$ & $31.16 \pm 0.86$ & $519.63 \pm 33.44$ & $411.28 \pm 18.59$ & $108.58 \pm 15.46$ & $3.97 \pm 0.33 *$ \\
\hline $100 \mu \mathrm{g} / \mathrm{L}$ & $0.67 \pm 0.00$ & $32.06 \pm 0.97$ & $567.66 \pm 36.37$ & $467.50 \pm 28.79$ & $100.28 \pm 7.68^{*}$ & $4.68 \pm 0.08 *$ \\
\hline ANOVA $p$ value & 0.148 & 0.126 & 0.385 & 0.674 & $<0.0001$ & $<0.0001$ \\
\hline
\end{tabular}

Co-1: Hoagland solution, Co-2: Hoagland solution $+0.004 \%$ of dimethyl sulfoxide, ChlaF: chlorophyll a fluorescence measured by Fv/Fm, SPAD: total chlorophyll measured by SPAD units, TChl: total chlorophyll measured by chemical extraction with N,N dimethylformamide, Chla: chlorophyll a, Chlb: chlorophyll b, Chla/b ratio: chlorophyll a divided chlorophyll b.

*Statistically significant to negative control at 0.05 level of probability (Tukey's test).

decrease at $100 \mu \mathrm{g} / \mathrm{L}$ AZX respect to the negative controls $(\mathrm{p}<0.05)$. Also, the $\mathrm{Chla} / \mathrm{b}$ ratio showed a statistically significant increase at 50 and $100 \mu \mathrm{g} / \mathrm{L}$ AZX with respect to the negative controls $(\mathrm{p}<0.05)$ (Table I).

\section{Experiment 2: Cytogenetic biomarkers}

The MI varied from 2.6 to 8.4 in Co- 1 plants, from 2.5 to 7.2 in Co-2 plants, from 2.9 to 8.1 in $\mathrm{Co}+$ plants, and from 5.3 to 11.9 in AZX-treated plants. In all cases, it was high enough to score the required number of cells for the cytogenetic analysis (Table II).

The CAM that included chromosomes not congregated at the metaphase equator showed a statistically significant increase in plants exposed to $0.1-100 \mu \mathrm{g} / \mathrm{L}$ AZX, with respect to plants exposed to negative controls $(p=0.0001)$ (Table III).

Among CAAT, only laggard chromosomes showed statistically significant changes between negative control plants and AZX-treated plants (Table III). This type of chromosomal aberration increased in plants exposed to $0.1-100 \mu \mathrm{g} / \mathrm{LAZX}$ (p $<0.0001$ ) (Table III).
Other chromosomal aberrations (OCA) observed, as c-mitosis and chromosome clumping, were found only in plants exposed to $\mathrm{Co}^{+}$and in some AZX-treated plants. However, their frequencies were not statistically different from the negative controls ( $\mathrm{p}>0.05)$ (Table III).

Regarding total CA, no differences between Co- 1 and Co- 2 plants were observed. On the other hand, a significant increase in total CA was found in $\mathrm{Co}^{+}$plants with respect to both negative controls (Table III). In addition, statistically significant increases were found in all AZX treatments compared to the negative controls $(\mathrm{p}<0.0001)$ (Table III). The chromosomal aberrations in mitotic root cells of $B$. laevis exposed to AZX are shown in figure 1.

\section{DISCUSSION}

Fungicides are extensively used in agriculture because they constitute the most effective method to control pathogenic fungi in crops. However, there is a growing concern about the environmental pollution generated by their use and their toxicity to non-target organisms.

TABLE II. MITOTIC INDEX (MI) IN ROOT CELLS OF Bidens laevis EXPOSED TO DIFFERENT AZOXYSTROBIN TREATMENTS. AVERAGE OF SIX REPLICATES \pm STANDARD ERROR

\begin{tabular}{|c|c|c|c|c|c|c|c|c|}
\hline & \multicolumn{3}{|c|}{ Controls } & \multicolumn{5}{|c|}{ Azoxystrobin $(\mu \mathrm{g} / \mathrm{L})$} \\
\hline & Co-1 & $\mathrm{Co}-2$ & $\mathrm{Co}+$ & 0.1 & 1 & 10 & 50 & 100 \\
\hline MI & $6.11 \pm 1.20$ & $5.41 \pm 0.72$ & $5.86 \pm 0.77$ & $6.91 \pm 0.58$ & $8.41 \pm 0.54$ & $7.94 \pm 0.48$ & $7.35 \pm 0.43$ & $9.20 \pm 0.86$ \\
\hline
\end{tabular}

Co-1: Hoagland solution, Co-2: Hoagland solution $+0.004 \%$ of dimethyl sulfoxide, $\mathrm{Co}+$ : methyl methanesulfonate at $10 \mathrm{mg} / \mathrm{L}$ 


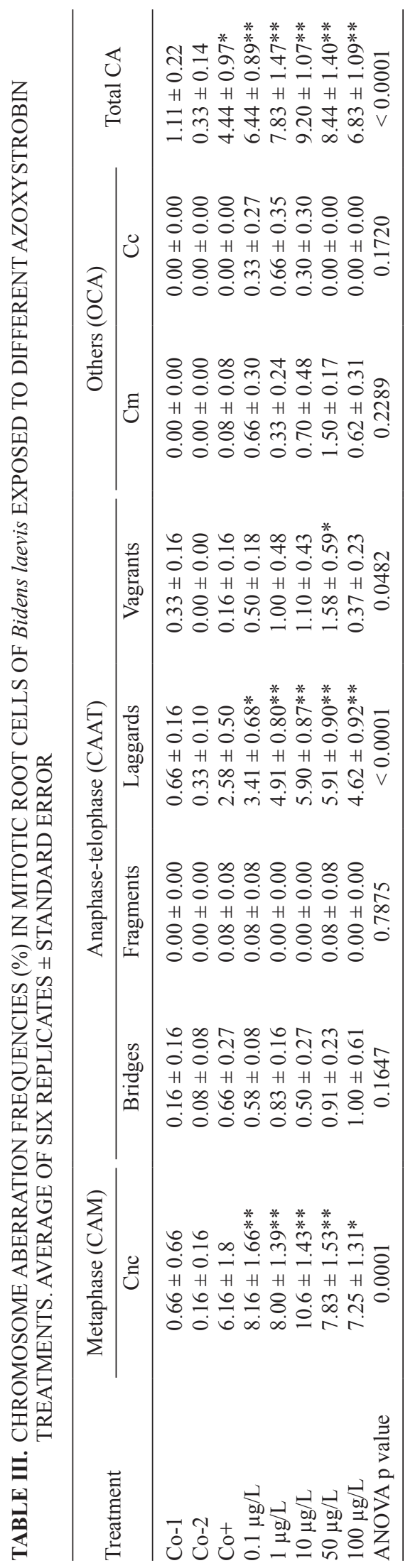

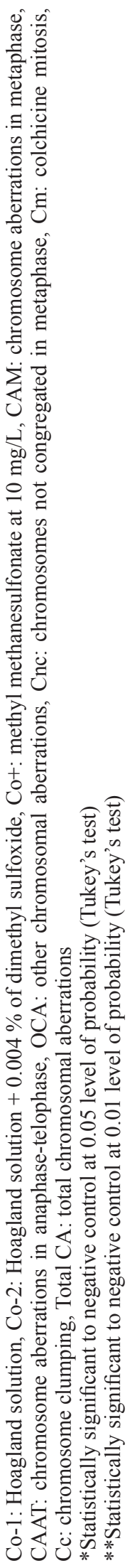

In this sense, the impact of the exposure to strobilurin fungicides on non-target aquatic and wetland macrophytes that inhabit close to agroecosystems has recently become a topic of research because the results obtained are useful to predict negative effects on wild plants. The present work addressed the potential use of Bidens laevis as a biomonitor plant to assess the potential physiological and cytogenetic effects of the widespread strobilurin fungicide AZX.

\section{Photosynthetic biomarkers}

The AZX is a systemic fungicide that affects respiration in fungi by inhibiting electron transport in mitochondria, leading to cellular oxidative stress and disruption of fungal metabolism and growth (Bartlett et al. 2002). Recent studies have indicated that AZX also disrupts mitochondrial respiration and induces DNA damage in fishes (Olsvik et al. 2010, Han et al. 2016, respectively).

In addition, Garanzini and Menone (2015) reported that AZX changes the activity of the antioxidant enzymes in the aquatic macrophyte Myriophyllum quitense, indicating that this fungicide induces oxidative stress in this non-target plant. This raised the possibility that AZX may interfere with photosynthetic activity. In fact, several fungicides are known to interfere with the metabolic pathways of plants in the photosynthetic process (Petit et al. 2012).

Nason et al. (2007) tested different strobilurin fungicides, including AZX, in soy, wheat and barley plants, and observed that fungicides had similar effects on plant physiology but differed in their persistence and potency. These authors also found that the application of fungicides to whole plants by using a spray gun-led to a decrease in the net rate of photosynthesis, compared to the leaves of control plants.

Although the mechanism of the photosynthetic effects is unknown, these authors hypothesized that strobilurin fungicides act directly on ATP production in guard cell mitochondria or by stomata responding to strobilurin-induced changes in mesophyll photosynthesis.

Nason et al. (2007) also observed that, shortly after exposure to AZX, plants were stressed, as revealed by a decrease in ChlaF, possibly due to a blockade in the electron transport between PSII and PSI, by binding to the $\mathrm{Q}_{\mathrm{i}}$ site of the chloroplast cytochrome bf complex. Although these findings were described after a short-term exposure to AZX (after 1, 3 and 7 days), AZX was applied directly over the leaves, whereas, in the present work, the plants were in contact with AZX through the roots. As B. laevis is a wetland species, the experiments were designed to 

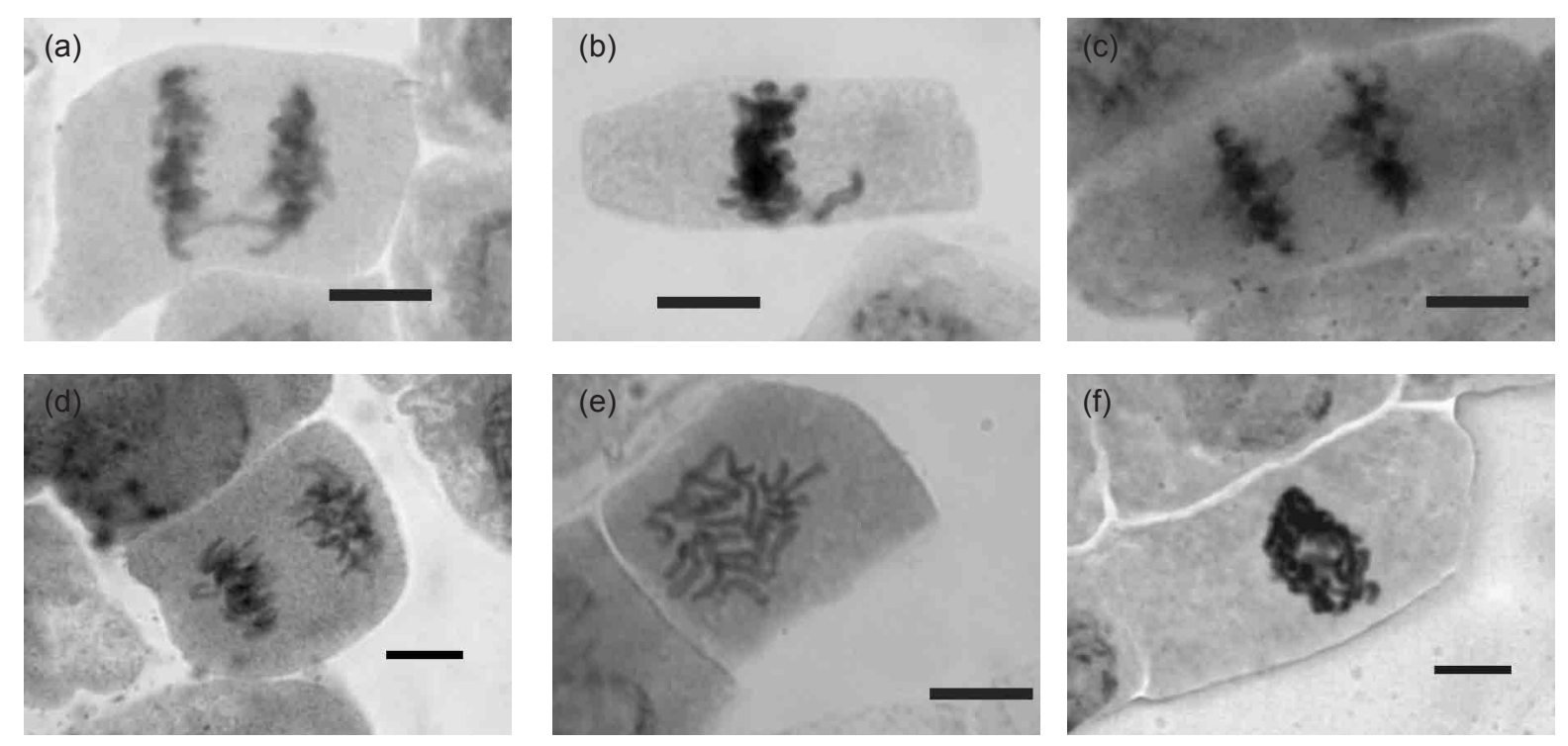

Fig. 1. Different types of chromosome aberrations in mitotic root cells of Bidens laevis exposed to azoxystrobin $(\times 1000)$ : (a) bridge, (b) chromosome not congregated, (c) laggard, (d) vagrant, (e) c-mitosis, (f) chromosome clumping. The bar indicates $5 \mu \mathrm{m}$

simulate a realistic condition in the field, in which an acute pulse of AZX could take place through runoff by root uptake.

The effects of AZX on the photosynthetic apparatus were assessed through SPAD and ChlaF. These measurements are common in plant ecophysiological studies, but are rare in ecotoxicological research. The analysis of these non-destructive optical measures did not allow us to observe AZX effects on B. laevis leaves.

The results showed only a decrease in Chlb at the highest AZX concentration tested through destructive chemical methods. This result is in agreement with those of Brain et al. (2004), who established that Chlb is generally more sensitive than Chla to be degraded under xenobiotic stress.

However, no changes were found in total chlorophyll content under any AZX treatment or in the other photosynthetic biomarkers tested (SPAD, ChlaF) (Table I). This lack of response in the photosynthetic biomarkers may be attributed to different possibilities. First, strobilurin fungicides have been shown to induce cytokinin synthesis (Grossmann and Retzlaff 1997).

It is well known that cytokinins increase the activity of RuBisCo, the main photosynthetic enzyme (Boonman et al. 2007) and, consequently, leaf photosynthetic capacity (Song et al. 2013). Cytokinins also promote tetrapyrrole biosynthesis (Yaronskaya et al. 2006) and often increase chlorophyll concentration.
It is therefore possible that any negative impact of AZX on the photosynthetic electron transport could be counterbalanced by a cytokinin-mediated effect.

Second, in the present work root tissues were directly exposed to the fungicide, and the exposure time might not have been enough to allow the translocation of AZX from roots to leaves. In that case, no effects on leaves could be expected, mostly taking into account that AZX is an organic compound with low lipophilicity $(\log$ Kow $=2.5)$ (US-EPA 2010).

Future studies should be carried out to determine root uptake and distribution rate in leaves, stems and flowers, as it has been done with the insecticide endosulfan in B. laevis (Pérez et al. 2013).

\section{Cytogenetic biomarkers}

In the present study, the high MI observed in all treatments were appropriate for the analysis of chromosomal aberrations in root cells of B. laevis, and similar to that found in previous reports using this wetland macrophyte (Pérez et al. 2011, 2014), and to the international standard protocol with Allium cepa (Rank 2003). These results indicate that the different AZX treatments induced no changes in the mitotic cycle (Table II).

The results showed that there were no statistically significant differences between the negative controls (Co-1 and Co-2), indicating that the aliquot of DMSO $(0.004 \%)$ used in plants exposed to $\mathrm{Co}-2$ did not 
affect the basal frequency of chromosomal aberrations in mitotic root cells of B. laevis (Table III).

Moreover, there were statistically significant differences between the negative controls and the positive control, indicating that MMS at $10 \mathrm{mg} / \mathrm{L}$ induced an increase in the total CA in somatic root cells of B. laevis (Table III). In addition, it is important to denote that MMS induced spindle disturbances at cytogenetic level in this plant, evidenced by higher frequencies of laggards and vagrants, as described in previous studies (Pérez et al. 2011, 2014).

Rank (2003) reported the clastogenic effect of MMS in Allium cepa, whereas Pérez (2012) reported that MMS $(10 \mathrm{mg} / \mathrm{L})$ induced DNA fragmentation in $B$. laevis, assessed by the comet assay, indicating the clastogenic effect of MMS on this plant.

Cytogenetic analyses are recognized as sensitive and reliable for the detection of mutagenic-genotoxic compounds. In particular, the chromosomal aberrations assay is a simple and low-cost technique that allows studying the mode of action of genotoxins in mitotic cells, depending on the different types of abnormalities observed.

In this sense, two types of chromosomal aberrations should be taken into account according to whether they are indicators of (1) spindle disturbance or aneunogenesis (including laggard or vagrant chromosomes) or (2) clastogenicity (including bridges, fragments and broken chromatids).

Other less frequent aberrations such as c-mitosis, multipolarity anaphases, polyploid cells, pulverized chromosomes and chromosome clumping, should also be scored (Rank 2003). The presence of fully condensed chromosomes randomly distributed in the cell or c-mitosis suggests a partial or total inhibition of spindle formation, which affects the metaphaseanaphase transition (Andrioli and Mudry 2011). Also, chromosomes not congregated in metaphase are indicators of spindle disturbance (Pérez et al. 2014).

In the present study, the results showed that the active ingredient of AZX increased the number of chromosomal aberrations in mitotic root cells at low concentrations from 0.1 to $100 \mu \mathrm{g} / \mathrm{L}$ in B. laevis (Table III).

The main types of chromosomal aberrations found were laggards in anaphase-telophase and chromosomes not congregated in metaphase, indicating that AZX induced spindle disturbances in mitotic root cells of $B$. laevis at environmentally relevant concentrations (Table III, Fig. 1).

The mechanism by which AZX induces spindle disturbances is still unknown. However, this could be elucidated by the analysis of the microtubule structure (immunoassay with labeled $\beta$-tubuline), as described by Andrioli et al. (2012) for the spindle disturbance induced by carbamate pesticides in $A$. cepa root cells.

Moreover, a recent study using the submerged aquatic macrophyte $M$. quitense exposed to the active ingredient of AZX showed that this fungicide causes genetic damage, as assessed at molecular level by the comet assay, since DNA fragmentation was found in plants exposed to 50 and $100 \mu \mathrm{g} / \mathrm{L}$ (Garanzini and Menone 2015).

In the present study, the basal frequencies of bridges and fragments did not change under AZX treatment, meaning that the AZX mode of action may not involve clastogenicity in B. laevis since plant responses to the active ingredient of AZX could vary according to the species.

The most relevant effect of AZX in B. laevis was mainly spindle disturbance, which can induce different types of abnormalities resulting in irreversible damage, because laggard chromosomes or chromosomes not congregated in metaphase can be lost in cells of the following generation. The genetic information contained in lost chromosomes or fragments can result in a valuable loss. Likewise, cell lineages that contain deficiencies will form deficient tissues, and then the viability and health of the plant in field conditions would decrease (Bickham et al. 2000).

This becomes more relevant when the affected lineages are part of the germinal cells (meiotic cells), because they may directly affect pollen viability and reproductive success. This last effect would lead to a demographic decline (demo-ecological effects) in the population (Bickham et al. 2000).

\section{CONCLUSION}

The present work showed the genotoxic effects of low $(0.1 \mu \mathrm{g} / \mathrm{L})$ and high $(100 \mu \mathrm{g} / \mathrm{L})$ concentrations of the strobilurin fungicide AZX on the mitotic root chromosomes of the wetland macrophyte $B$. laevis. The AZX mode of action in root cells of $B$. laevis was mainly by spindle disturbance, because the chromosomal aberrations most frequently found were laggards in anaphase-telophase and chromosomes not congregated in metaphase.

Physiological biomarkers related with the photosynthetic apparatus were less affected by AZX. The only significant effect was a decrease in Chlb levels, assessed by a traditional destructive chemical method, in plants exposed at the maximum AZX concentration tested. On the other hand, no effects 
of AZX were detected by non-destructive methods used to analyze ChlaF and SPAD units.

The results showed that the chromosomal aberrations in mitotic root cells constitute a more sensitive biomarker of early effects than the physiological biomarkers studied, at least for the acute exposure used in this work.

\section{ACKNOWLEDGMENTS}

This work was supported by Fondo para la Investigación Científica y Tecnológica (PICT 2014-1460) granted to Débora J. Pérez, Fondo para la Investigación Científica y Tecnológica (PICT 2013-1348), Consejo Nacional de Investigaciones Científicas y Técnicas (PIP 112-201- 101-01084 2011), Universidad Nacional de Mar del Plata (EXA 702/14) granted to Mirta L. Menone, Universidad Nacional de Mar del Plata (AGR 535/17) and Comisión de Investigaciones Científicas (CIC 2017) granted to Jorge A. Tognetti.

\section{REFERENCES}

Andrioli N.B. and Mudry M.D. (2011). Cytological and cytogenetic effects induced by thiabendazole on $\mathrm{Al}$ lium cepa root meristems. J. Basic Appl. Genet. 22 (2), 17-23.

Andrioli N.B., Soloneski S., Larramendy M.L. and Mudry M.D. (2012). Cytogenetic and microtubule array effects of the zineb-containing commercial fungicide formulation Azzurro ${ }^{\circledR}$ on meristematic root cells of Allium cepa L. Mutat. Res. 742 (1-2), 48-53.

DOI: 10.1016/j.mrgentox.2011.11.014

Balba H. (2007). Review of strobilurin fungicide chemicals. J. Environ. Sci. Heal. B. 42 (4), 441-451.

DOI: $10.1080 / 03601230701316465$

Bartlett D.W., Clough J.M., Godwin J.R., Hall A.A., Hamer M. and Parr-Dobrzanski B. (2002). The strobilurin fungicides. Pest. Manag. Sci. 58 (7), 649-662. DOI: $10.1002 /$ ps. 520

Battaglin W.A., Sandstrom M.W., Kuivila K.M., Kolpin D.W. and Meyer M.T. (2011). Occurrence of azoxystrobin, propiconazole, and selected other fungicides in US streams, 2005-2006. Water Air Soil Poll. 218 (1-4), 307-322. DOI: 10.1007/s11270-010-0643-2

Berenzen N., Lentzen-Godding A., Probst M., Schulz H., Schulz R. and Liess M. (2008). A comparison of predicted and measured levels of runoff-related pesticide concentrations in small lowland streams on a landscape level. Chemosphere 58 (5), 683-691. DOI: 10.1016/j. chemosphere.2004.05.009
Bickham J.W., Sandhu S., Hebert P.D.N., Chikhi L. and Athwal R. (2000). Effects of chemical contaminants on genetic diversity in natural populations: Implications for biomonitoring and ecotoxicology. Mutat. Res. 463 (1), 33-51.

DOI: $10.1016 / \mathrm{S} 1383-5742(00) 00004-1$

Boonman A., Prinsen E., Gilmer F., Schurr U., Peeters A.J.M., Voesenek L.A.C.J. and Pons T.L. (2007). Cytokinin import rate as a signal for photosynthetic acclimation to canopy light gradients. Plant. Physiol. 143 (4), 1841-1852.

DOI: $10.1104 /$ pp. 106.094631

Brain R.A., Johnson D.J., Richards S.M., Hanson M.L., Sanderson H., Lam M.W., Young, C., Mabury S.A., Sibley P.K. and Solomon K.R. (2004). Microcosm evaluation of the effects of an eight pharmaceutical mixture to the aquatic macrophytes Lemna gibba and Myriophyllum sibiricum. Aquat. Toxicol. 70 (1), 23-40. DOI:10.1016/j.aquatox.2004.06.011

Brain R.A. and Cedergreen N. (2008). Biomarkers in aquatic plants: Selection and utility. Rev Environ. Contam. Toxicol. 198, 49-109.

DOI: 10.1007/978-0-387-09647-6_2.

Garanzini D.S. and Menone M.L. (2015). Azoxystrobin causes oxidative stress and DNA damage in the aquatic macrophyte Myriophyllum quitense. B. Environ. Contam. Tox. 94 (2), 146-151.

DOI: $10.1007 / \mathrm{s} 00128-014-1428-\mathrm{x}$

Grant W.F. and Owens E. (2002). Chromosome aberration assays in Pisum for the study of environmental mutagens. Mutat. Res. 488 (2), 93-118.

DOI: $10.1016 / \mathrm{S} 1383-5742(00) 00064-8$

Grossman K. and Retzlaff G. (1997). Bioregulatory effects of the fungicidal strobilurin kresoxim-methyl in wheat (Triticum aestivum). Pestic. Sci. 50 (1), 11-20.

DOI: 10.1002/(SICI)1096-9063(199705)50: $1<11::$ AID-PS556>3.0.CO;2-8

Gupta R.C. (2014). Introduction. In: Biomarkers in toxicology (Gupta R.C., Ed.). Elsevier, San Diego, USA, 3-5. DOI: $10.1016 / \mathrm{C} 2012-0-01373-7$

Han Y., Liu T., Wang J., Wang J., Zhang C. and Zhu L. (2016). Genotoxicity and oxidative stress induced by the fungicide azoxystrobin in zebrafish (Danio rerio) livers. Pestic. Biochem. Phys. 133, 13-19. DOI: $10.1016 /$ j.pestbp.2016.03.011

Hugget R.J., Kimerle R.A., Mehrle P.M., Bergman H.L., Dickson K.L., Fava J.A., McCarthy J.F., Parrish R., Dorn P.B., McFarland V. and Lahvis G. (1992). Introduction. In: Biomarkers: Biochemical, physiological, and histological markers of anthropogenic stress (Hugget R.J., Kimerle R.A., Mehrle P.M. and Bergman L.H., Eds.). Lewis Publishers, Chelsea, USA, pp 1-3. 
Inskeep W.P. and Bloom P.R. (1985). Extinction coefficients of chlorophyll $\mathrm{a}$ and $\mathrm{b}$ in N,N-dimethylformamide and 80\% acetone. Plant Physiol. 77 (2), 483-485. DOI: $10.1104 /$ pp.77.2.483

Krugh B.W. and Miles D. (1996). Monitoring the effects of five "nonherbicidal" pesticide chemicals on terrestrial plants using chlorophyll fluorescence. Environ. Toxicol. Chem. 15 (4), 495-500.

DOI: $10.1002 /$ etc. 5620150413

Lahitte H.B. and Hurrell J.A. (1997). Plantas de la costa. Literature of Latin America (L.O.L.A). Colin Sharp, Buenos Aires, Argentina, 200 pp.

Maltby L., Arnold D., Arts G., Davies J., Heimbach F., Pickl C. and Poulsen V. (2010). Aquatic macrophyte risk assessment for pesticides. CRC Press, Boca Raton, USA, $135 \mathrm{pp}$.

Menone M.L., Pérez D.J., Lukaszewicz G. and Camadro E.L. (2015). Identification of freshwater hydrophytes for genotoxicity assessment of aquatic pollutants. J. Basic Appl. Genet. 26 (1), 9-17.

Nason M.A., Farrar J. and Bartlett D. (2007). Strobilurin fungicides induce changes in photosynthetic gas exchange that do not improve water use efficiency of plants grown under conditions of water stress. Pest. Manag. Sci. 63 (12), 1191-1200. DOI: 10.1002/ps. 1443

Nichols P.B., Couch J.D. and Al-Hamdani S.H. (2000). Selected physiological responses of Salvinia minima to different chromium concentrations. Aquat. Bot. 68 (4), 313-319. DOI: 10.1016/S0304-3770(00)00128-5

Olsvik P.A., Kroglund F., Finstad B. and Kristensen T. (2010). Effects of the fungicide azoxystrobin on Atlantic salmon (Salmo salar L.) smolt. Ecotox. Environ. Safe. 73 (8), 1852-1861.

DOI: 10.1016/j.ecoenv.2010.07.017

Pérez D.J., Menone M.L., Camadro E.L. and Moreno V.J. (2008). Genotoxicity evaluation of the insecticide endosulfan in the wetland macrophyte Bidens laevis L. Environ. Pollut. 153 (3), 695-698. DOI: 10.1016/j.envpol.2007.09.014

Pérez D.J., Lukaszewicz G., Menone M.L. and Camadro E.L. (2011). Sensitivity of Bidens laevis L. to mutagenic compounds. Use of chromosomal aberrations as biomarkers of genotoxicity. Environ. Pollut. 159 (1), 28-286. DOI: 10.1016/j.envpol.2010.08.028

Pérez D.J. (2012). Potencial de Bidens laevis L., macrófita común de ambientes lagunares, como bimonitor de efectos genotóxicos del insecticida endosulfán. Tesis de doctorado. Facultad de Ciencias Agrarias, Universidad Nacional de Mar del Plata, Balcarce, Argentina, 186 pp.
Pérez D.J., Menone M.L. and Doucette W.J. (2013). Rootto-shoot transfer and distribution of endosulfan in the wetland macrophyte Bidens laevis L. Environ. Toxicol. Chem. 32 (11), 2478-2481 DOI: 10.1002/etc.2343

Pérez D.J., Lukaszewicz G., Menone M.L., Amé M.V. and Camadro E.L. (2014). Genetic and biochemical biomarkers in the macrophyte Bidens laevis L. exposed to a commercial formulation of endosulfan. Environ. Toxicol. 29 (9), 1063-1071. DOI: 10.1002/tox.21836

Pérez D.J., Okada E., De Gerónimo E., Menone M.L., Aparicio V.C. and Costa J.L. (2017). Spatial and temporal trends and flow dynamics of glyphosate and other pesticides within an agricultural watershed in Argentina. Environ. Toxicol. Chem. 36 (12), 32063216, DOI: 10.1002/etc.3897

Petit A.N., Fontaine F., Vatsa P., Clément C. and VaillantGaveau N. (2012). Fungicide impacts on photosynthesis in crop plants. Photosynth. Res. 111 (3), 315-326. DOI: $10.1007 / \mathrm{s} 11120-012-9719-8$

Rank J. (2003). The method of Allium anaphase-telophase chromosome aberration assay. Ekologija 1, 38-42.

Richardson, A.D., Duigan S.P. and Berlyn G.P. (2001). An evaluation of noninvasive methods to estimate foliar chlorophyll content. New Phytol. 153 (1), 185-194. DOI: 10.1046/j.0028-646X.2001.00289.x

Rodrigues, E.T., Lopes I. and Pardal M.A. (2013). Occurrence, fate and effects of azoxystrobin in aquatic ecosystems: A review. Environ. Int. 53, 18-28.

DOI: 10.1016/j.envint.2012.12.005

Song W., Li J., Sun H., Huang S., Gong X., Ma Q., Zhang Y. and Xu G. (2013). Increased photosynthetic capacity in response to nitrate is correlated with enhanced cytokinin levels in rice cultivar with high responsiveness to nitrogen nutrients. Plant Soil 373 (1-2), 981-993. DOI: $10.1007 / \mathrm{s} 11104-013-1867-\mathrm{x}$

US-EPA (2010). DP\#376966 azoxystrobin. Summary of analytical and chemistry residue data. United State Environmental Protection Agency, Washington, D.C., USA, 15 pp.

Yaronskaya E., Vershilovskaya I., Poerz Y., Alawady A.E., Averina N. and Grimm B. (2006). Cytokinin effects on tetrapyrrole biosynthesis and photosynthetic activity in barley seedlings. Planta 224 (3), 700-709.

DOI: $10.1007 / \mathrm{s} 00425-006-0249-5$ 